Syntax Fusion : Jurnal Nasional Indonesia

P-ISSN: $x x x x-x x x x$

E-ISSN : $x x x x-x x x x$

Vol. 1, No. 2, Februari 2021

\title{
METODE PEMBINAAN PENDIDIKAN AGAMA ISLAM PEMUDA HIJRAH (STUDI TERHADAP KEgIATAN PEMBINAAN KOMUNITAS PEMUDA HIJRAH)
}

\author{
Muhammad Nur Rahman \\ STAI Persis Bandung \\ E-mail: Reyrachman17@gmail.com
}

\begin{abstract}
Abstrak
Pembinaan merupakan usaha, tindakan dan kegiatan yang diadakan secara berdaya dan berhasil, guna untuk memperoleh hasil yang lebih baik. Pembinaan juga dapat berarti suatu kegiatan yang mempertahankan dan menyempurnakan apa yang telah ada sesuai dengan yang diharapkan. Penelitian ini bertujuan untuk mengetahui bentuk kegiatan pembinaan pendidikan agama Islam yang dilaksanakan oleh komunitas pemuda hijrah, beberapa materi ajar yang dipakai oleh komunitas pemuda hijrah, dan metode pembinaan yang sering mereka gunakan sehingga dapat menunjang keberhasilan dari peningkatan kualitas keimanan dan ketaqwaan pada manusia, terkhusus bagi para pemuda yang ingin berhijrah. Penelitian ini merupakan salah satu upaya optimalisasi dalam proses pendidikan nonformal, setiap kegiatan pendidikan yang diselenggarakan di luar sistem persekolahan, baik yang di lembagakan ataupun yang tidak dengan maksud memberi layanan kepada sasaran didik dalam rangka mencapai tujuan belajar, yang kegiatan mengajarnya tidak harus berjenjang dan berkesinambungan. Penelitian ini dilakukan dengan menggunakan metode deskriptif, yang bertujuan untuk menggali metode pembinaan pendidikan agama Islam Pemuda Hijrah, diantaranya adalah menuturkan, menganalisa, dan mengklasifikasi pembinaan komunitas pemuda hijrah tentang bentuk kegiatan, materi, dan metode pembinaan pendidikan agama Islam dengan teknik pengumpulan data secara pasti. Teknik pengumpulan data ini dengan melakukan observasi, wawancara, dan pengumpulan dokumen dengan pihak yang bersangkutan.
\end{abstract}

Kata Kunci: Pemuda Hijrah, Meode Pembinaan, Pendidikan Agama Islam

\section{Pendahuluan}

Manusia merupakan makhluk yang dilahirkan dalam keadaan lemah dan tidak berdaya, namun dengan demikian ia telah mempunyai potensi bawaan yang bersifat laten. Dalam perkembangannya manusia dipengaruhi oleh pembawaan dan lingkungan, dan 
salah satu sifat hakiki manusia adalah mencapai kebahagiaan, dan untuk mencapai kebahagiaan itu manusia membutuhkan agama. Agama adalah aturan-aturan dari Tuhan Yang Maha Esa, petunjuk kepada manusia agar dapat selamat dan sejahtera hidupnya di dunia dan akhirat dengan petunjuk serta teladan-teladan Nabi beserta kitabnya. (Famularsih \& Billah, 2014, p. 88)

Apabila manusia telah memilih suatu agama sebagai anutan, ia berkewajiban untuk melaksanakan ajaran dari perintah-perintah agama tersebut. Dalam pelaksanaan ajaranajaran agama, setiap pemeluk agama (Islam) diharapkan dapat melaksanakan atau mengamalkan ajaran-ajaran agamanya dalam kehidupan sehari-hari seperti adanya kewajiban untuk menjalankan ibadah sholat, puasa, zakat, dan haji. Bahkan bagi umat Islam seluruh kehidupannya idealnya adalah untuk beribadah kepada Allah SWT.

Salah satu usaha untuk memahami dan mengamalkan agama dengan baik dan benar adalah melalui pendidikan, yaitu pendidikan agama Islam. Hingga saat ini, pendidikan agama Islam di sekolah menghadapi berbagai tantangan, baik internal maupun eksternal. Secara internal, pendidikan agama di sekolah dianggap kurang berhasil dalam menggarap sikap dan perilaku keberagamaan peserta didik serta membangun moral dan etika bangsa. (Muhaimin, 2001, p. 305)

Kenyataan semacam itu sudah tidak dapat dibendung lagi, sehingga pendidikan agama Islam lebih berperan untuk memberikan filter atau menyaring nilai-nilai mana yang boleh diambil dan yang tidak boleh diambil (Muhaimin, 2001, p. 305). Maka dari itu, masyarakat juga berkewajiban memberikan pendidikan bagi anggotanya atau biasa disebut pendidikan yang bersifat informal. Memang diakui bahwa pengaruh masyarakat berperan besar dalam pembentukan kepribadian anak. Hal ini dikarenakan sosial budaya masyarakat mudah dijadikan acuan anak-anak dalam mencontoh perkataan dan perbuatannya.(Famularsih \& Billah, 2014, pp. 90-91)

J. Drost mengemukakan perlunya pendidikan integratif, yang tidak hanya dipikulkan pada lembaga sekolah, ia menyebutkan bahwa seluruh proses pemuliaan ialah pembentukan moral manusia muda hanya mungkin lewat interaksi informal antara dia dan lingkungan hidup manusia muda itu. Jadi, kesimpulan yang paling mendasar ialah bahwa lembaga pertama dan utama pembentukan dan pendidikan adalah keluarga. Sekolah hanyalah lembaga yang mewakili tugas orang tua dalam penyelenggaraan pendidikan yang menjadi tanggungjawab keluarga dan masyarakat. (Bambang \& Hambali, 2008, p. 116)

Keberhasilan pendidikan agama Islam tidak bisa begitu saja tanpa peran keluarga dan masyarakat. Keluarga menjadi pemain utama pendidikan nilai Islami dan karenanya harus dilibatkan dalam proses dan strategi pendidikan agama Islam. Pendidikan agama Islam pada dasarnya harus menyentuh tiga aspek secara terpadu, yaitu: (1) knowing, yakni agar peserta didik dapat mengetahui dan memahami ajaran dan nilai-nilai agama; (2) doing, yakni agar peserta didik dapat mempraktikan ajaran dan nilai-nilai agama; dan (3) being, yakni agar peserta didik dapat menjalani hidup sesuai dengan ajaran dan nilai-nilai agama. Jika pendidikan agama Islam hanya mengandalkan pada proses belajar-mengajar di dalam atau di luar kelas yang hanya tiga jam pelajaran untuk jenjang pendidikan dasar, 
atau dua jam pelajaran untuk jenjang pendidikan SMP dan SMA/SMK, maka mustahil aspek being akan bisa tercapai. Aspek knowing dan doing hanya bisa mencapai dimensi otak dan badan, kedua aspek ini merupakan landasan bagi tercapainya aspek being.(Muhaimin, 2001, pp. 305-306)

Pemuda Hijrah adalah salah satu komunitas yang fokus pada pembinaan keagaaman untuk masyarakat umum. Lebih khususnya lagi untuk para pemuda dan remaja yang semasa hidupnya kurang memahami tentang agama Islam, bahkan jauh dari dunia Islam, yang pada akhirnya ingin mempelajari tentang agama Islam. Pemuda hijrah ini menghimpun beberapa anggota yang terdiri dari pemuda yang masuk pada geng motor, geng anak jalanan atau punk, dan anak skateboard yang dulunya sering berbuat kesalahan sehingga mereka memutuskan untuk berhijrah, memperbaiki diri agar kembali ke jalur yang benar. Pemuda hijrah mempunyai strategi dan metode pembinaan keagamaan yang membuat para remaja itu tertarik untuk mengikuti setiap kegaiatanya. Dengan bertujuan untuk menyadarkan mereka agar kembali ke jalan yang benar dan beribadah kepada Allah SWT.

Maka dari itu, metode dan strategi yang dilakukan oleh komunitas Pemuda Hijrah ini yang berinisiatif untuk menyadarkan kembali dan mengajarkan tentang keagamaan, membantu mengurangi permasalahan yang timbul di sekolah-sekolah umum yang hanya memberikan pengajaran tentang agama Islam sekitar dua sampai tiga jam saja. Perlulah kita mengetahui bagaimana metode pembinaan keagamaan yang di lakukan oleh komunitas pemuda hijrah ini sebagai proses pendidikan integratif yang masuk pada aspek knowing, doing, dan being.

\section{Metode Penelitian}

Metode yang digunakan penulis dalam penelitian ini adalah metode Deskriptif, bertujuan untuk menggali metode pembinaan pendidikan agama Islam Pemuda Hijrah, diantaranya adalah menuturkan, menganalisa, dan mengklasifikasi pembinaan komunitas pemuda hijrah tentang bentuk kegiatan, materi, dan metode pembinaan pendidikan agama Islam dengan teknik pengumpulan data secara pasti. Adapun jenis data dari penelitian ini adalah tentang Metode Pembinaan Pendidikan Agama Islam Pemuda Hijrah; Penelitian terhadap Kegiatan Pembinaan Komunitas Pemuda Hijrah yang meliputi: benttuk kegiatan, materi, dan metode pembinaan Pendidikan Agama Islam yang mereka programkan. Yang menjadi sumber data skripsi ini adalah komunitas pemuda hijrah dan para pengurusnya. Sedangkan sumber data sekundernya adalah sumber-sumber lain dari buku-buku, jurnal, majalah atau naskah yang lainnya, sesuai judul yang bersangkutan, dengan kata lain yang mendukung.

\section{Hasil dan Pembahasan}

\section{Perkembangan Komunitas Pemuda Hijrah}

Sejak berdirinya komunitas pemuda hijrah pada tahun 2015 mengalami naik dan turun dari proses perencanaan pembinaan yang melibatkan seluruh pengurus yang ada. Tidak bakunya sistem perekrutan dan program pembinaan yang berubah-ubah membuat 
komunitas pemuda hijrah ini mengibaratkan manajemennya itu seperti warung, belum menjadi seperti carefour atau trans studio mall. Maknanya ialah siapa saja yang ingin menjadi pengurus pemuda hijrah dan siap menjadi pembinanya, asalkan amanah dan jujur serta siap belajar bersama tentang agama Islam, mereka langsung merekrutnya.

Dengan perekrutan seperti itu, terjalin suatu komitmen dari para pengurus dan anggotanya agar lebih dimaksimalkan kembali dalam manajemen komunitas yang mereka bentuk. Strategi, tujuan, metode, dan program kegiatan pembinaan pemuda hijrah ini dijadikan suatu sistem yang baku namun tidak memberlakukan aturan yang ingin masuk menjadi anggota. Syaratnya pun sederhana, sering nongkrong, ikut kajian, dan mengikuti seluruh rangkaian kegiatan yang telah dijadwalkan, mereka ikut dan belajar bersama. Dengan cara seperti ini, sampai tahun sekarang, pemuda hijrah beranggotakan 100 orang lebih dengan berbagai latar belakang, ada yang dulunya anak gang motor, anak jalanan, anak skateboard, dan anak clubbing menjadi pembeda, karena lahan dakwah mereka itu semakin terbuka dengan cara merangkul mereka dan mengajak mereka untuk berhijrah, dari dunia yang gelap menjadi terang.

Ustadz Hanan Attaki, selaku founder dan penanggungjawab komunitas pemuda hijrah ini mengharapkan bagi seluruh aktivis dakwah yang ada di dunia ini memperhatikan mereka dan jadikanlah mereka sebagai lahan dakwah untuk kemajuan agama Islam di tahun-tahun berikutnya, karena mereka adalah asset bangsa dan asset Islam, kalau bukan kita siapa lagi, kalau bukan Islam, mau jadi apa mereka ketika di akhirat nanti.

\section{Program Pembinaan Pendidikan Agama Islam Pemuda Hijrah}

Ada beberapa kegiatan pembinaan yang dilakukan oleh Pemuda Hijrah untuk menstimulasi pemahaman agama Islam pada ring III dan IV, diantaranya:

a. Kajian KeIslaman

Kajian keIslaman ialah salah satu strategi pemuda hijrah dalam mengamalkan dan memberi pemahaman kepada Ring III dan Ring IV untuk mengetahui dasar-dasar tentang ajaran agama Islam.

Materi yang disampaikannya pun ringan, meliputi: Aqidah dan Akhlaq. Cara penyampaian kepada mereka pun dengan bahasa yang ringan, disesuaikan dengan karakteristik mereka sehari-hari agar mudah dipahami oleh mereka.

Contohnya, ketika mengkaji tentang Tauhid. Pada dasarnya tauhid itu mengajarkan kepada manusia untuk meyakini bahwa Allah SWT itu satu, tidak ada tuhan selain Allah. Dan dimanapun ketika kita berada, entah itu di perjalanan atau sedang tidur, Allah SWT selalu ada dengan kita, selalu mengawasi gerak langkah kita di dunia ini. Bilamana kita melakukan suatu kesalahan atau kekeliruan, ada yang mencatatnya yaitu para malaikat Allah yang telah ditugaskan oleh-Nya.

Kajian keIslaman ini pengisinya ada dua orang, yaitu ustadz Hanan Attaki dan ustadz Imam Nuryanto. Jadwalnya pada Hari Rabu dan Sabtu. Hari Rabu dari pukul 18.00selesai pengisinya ustadz Imam Nuryanto, dan Hari Sabtu dari pukul 18.00-selesai 
pengisinya ustadz Hanan Attaki. Lokasi kajiannya itu di Masjid Al-Lathif, jl. Saninten No. 02 Bandung dan Masjid TSM (Trans Studio Mall), jl. Gatot Subroto, Bandung.

a. Shift Ulin

Shift Ulin ialah salah satu kegiatan pembinaan yang berbasis pada pengekspresian diri dari para peserta yang ikut pada komunitas pemuda hijrah. Ada yang hobbynya Skateboard, Parkour, Sepeda BMX Style, Musik, Snorkling, Papan Seluncur, dan lainlain. Bilamana mereka sudah beres bermain hingga menambah banyak teman dan bersilaturahmi dengan orang-orang yang hobbynya sama, ketika adzan berkumandang mereka langsung diajak untuk sholat berjamaah dengan imam ustadz Hanan Attaki.

Inilah salah satu strategi Pemuda Hijrah untuk bisa merangkul mereka dengan memfasilitasi semua hobby mereka, ketika itu sudah terpenuhi, langsung diajak untuk beribadah kepada Allah SWT yaitu dengan menjalankan solat lima waktu secara berjamaah.

b. Giving Every Day

Giving every day ialah ajakan untuk bersedekah setiap hari. Bentuk kegiatannya disesuaikan dengan potensi diri yang ada pada diri peserta yang ikut dalam kegiatan ini. Apabila ada yang bisa potong rambut, semir sepatu, olahraga panahan, skateboard, sepeda BMX, dan lain-lain, mereka tidak akan mematok berapa harga yang biasanya di tarif. Semuanya gratis karena mereka diajarkan untuk bersedekah di setiap harinya agar mendapat keberkahan.

Potensi dari kegiatan ini ialah banyaknya proses interaksi sosial sesama manusia yang memiliki kemampuan yang berbeda-beda. Mereka bisa saling mengajarkan dan memberi pengalaman lebih kepada temannya. Pada ranah pendidikan, potensi ini masuk pada ruang lingkup pengembangan bakat dan kecerdasan seseorang yang termasuk pada multiple intelligence, kecerdasan pada gerak motorik dan kinestetik.

Pada program ini akan ada rencana untuk pembangunan sebuah taman di halaman masjid Al-Lathief yang akan di isi oleh banyaknya tempat bermain bagi para pemuda, sesuai dengan potensi yang mereka miliki. Ada space untuk anak skateboard, parkour, olah raga; panahan, basket, futsal, pijat refleksi, potong rambut, dan lain sebagainya.

c. Qiyamul Lail

Qiyamul lail ialah ajakan kepada seluruh elemen masyarakat untuk bangun di sepertiga malam dan melaksanakan sholat tahajud secara berjamaah. Ketika sudah beres, dilanjutkan dengan ceramah singkat dari imam qiyamul lail, sharing tentang indahnya beribadah di malam hari seperti yang dilakukan oleh Rasulullah SAW.

\section{d. Tahsin dan Tahfidz}

Tahsin dan tahfidz ialah salah satu bentuk pengajaran Alquran kepada peserta yang ikut dalam program ini. Tahsin ini mengajarkan cara membaca Alquran secara fasih dan sesuai dengan hukum tajwidnya. Bilamana ada peserta yang belum bisa membaca Alquran, ada pembinaan khusus yang dilakukan oleh Pemuda Hijrah ini. Dimulai dari 
memperkenalkan huruf-huruf hijaiyyah dan makharijul hurufnya agar mereka bisa mengikuti dan lancar dalam membaca Alquran.

Metode yang dipakai dalam tahsin ini ialah maqomat, yaitu belajar lagam dari para hafidz yang sudah ada. Seperti, Muzammil Hasballah, dan lain-lain. Bilamana mereka sudah bisa, dilanjutkan dengan menghafal atau biasa disebut dengan Tahfidz. Materi hafalannya ialah surat-surat yang ada di dalam Alquran hingga mereka bisa mengamalkannya ketika waktu sholat lima waktu.I

\section{e. Pemuda Hijrah Peduli}

Pemuda hijrah peduli ialah salah satu bentuk gerakan sosial untuk membantu saudara-saudara muslim yang sedang terkena musibah atau teror yang dilakukan oleh musuh-musuh Islam. Mereka menghimpun biaya dari para donatur untuk nanti diakumulasikan dan mendistribusikan kepada para pengungsi tepat di lokasi bencana. Yang sudah berjalan yaitu ketika teror yang ada di Suriah. Mereka bagi-bagi donasi dan shooting sekaligus dijadikan bentuk laporan kepada para donatur, telah terdistribusi bantuan yang telah mereka berikan.

\section{f. Ladies Day}

Ladies day ialah salah satu pengkhususan majlis taklim yang diadakan di masjid Trans Studio Mall dengan pembahasan seputar permasalahan para akhwat atau wanita. Jadwal kajiannya setiap hari Rabu pagi dimulai dari jam delapan pagi sampai selesai dengan pemateri ustadzah Haneen, istri dari ustadz Hanan Attaki. Kegiatannya kajian, olahraga, panahan, bermain, dan sharing permasalahan yang ada pada diri wanita.

Tujuan kegiatan ladies day ini ialah untuk memfasilitasi para wanita yang ingin mempelajari lebih dalam lagi mengenai kewajiban seorang wanita menurut Alquran dan Hadits, bagaimana cara hidup sehat dengan menutup aurat, dan lain-lain sesuai dengan usulan tema atau pembahasan yang di inginkan oleh para wanita.

Semua kegiatan pembinaan ini adalah strategi market dakwah agar masyarakat umum, khususnya para pemuda, sadar akan pentingnya kebersamaan yang diajarkan oleh Islam, bagaimana kita selaku manusia, makhluk sosial yang memang perlu bantuan orang lain, salah satunya ialah sharing pemahaman tentang ajaran agama Islam bila tidak ada orang yang memfasilitasi itu semua, mau dikemanakan para pemuda penerus perjuangan Islam ini ke depannya?

Kegiatan pembinaan pemuda hijrah mempunyai cita-cita, bahwa kita hari ini dalam berdakwah dan menyebarkan virus agama Islam itu harus mampu merangkul semua kalangan tidak hanya satu atau yang dekat dengan kita saja, banyak di sekitar kita pun yang mesti di selamatkan dari pergaulan yang dialrang oleh Allah SWT dan Rasul-Nya.

b. Materi Pembinaan Pendidikan Agama Islam Komunitas Pemuda Hijrah

1. Aqidah (Tauhid), materi yang disampaikannya mengenai permasalahan keyakinan, kepercayaan, tata cara mendekatkan diri kepada Allah SWT, mengetahui segala larangan dan perintahnya, kemudian diamalkan pada kehidupan sehari-hari dengan berproses. 
2. Akhlak, materi yang disampaikannya mengenai kisah dari Rasulullah SAW dan para sahabat, mengambil hikmah dari perjuangan dakwah Rasulullah SAW yang menyebarkan agama Islam, mengambil sebuah karakteristik dari perbuatan dan perkataan Rasulullah SAW hingga menjadi teladan bagi mereka.

3. Studi Alquran, materi yang disampaikannya mengenai tata cara membaca dan menghafal Alquran beserta tajwid dan tafsirnya agar mereka mampu mendalami setiap makna yang tersirat di dalam Alquran kemudian mengambil hikmah dalam setiap kisah yang ada, dan menjadi hafidz Alquran yang harus diamalkan ketika mereka solat lima waktu.

c. Metode Pembinaan Pendidikan Agama Islam Komunitas Pemuda Hijrah

a. Metode Freshcare

Metode freshcare ialah cara penyampaian tentang ajaran agama Islam dengan menggunakan istilah-istilah yang sering digunakan oleh ring III dan ring IV. Bahasa-bahasa yang ringan, namun esensi nilai-nilai keislamannya itu sampai. Kenapa dinamakan freshcare? Pada dasarnya bahan freshcare sama dengan minyak kayu putih, bila dianalogikan pada segmentasi dakwah tadi, minyak kayu putih itu ibarat dengan ring I dan II, yang sering dipakai oleh bapak-bapak atau ibu-ibu, yang notabene mereka sudah paham bahan dasar dari minyak kayu putih karena sering dan banyak di pakai oleh banyak kalangan, begitu juga dengan pemahaman mereka tentang ajaran agama Islam dianggap sudah faham dan mengerti.

Berbeda dengan ring III dan ring IV, perlu adanya inovasi yang baru. Awalnya minyak kayu putih, diubah menjadi freshcare, kemasan yang baru, di branding oleh artis, dan bisa dibeli oleh anak-anak muda dan ringan untuk dibawa kemana-mana. Darisinilah, metode freshcare ini menyuguhkan gaya baru dengan mengemas mater-materi tentang ajaran agama Islam yang bisa masuk dan diterima oleh ring III dan ring IV. Materi pendidikan agama Islam yang menggunakan metode freshcare ini ialah Aqidah dan Akhlak.

Ada dua cara dalam penyampaian materi pendidikan agama Islam dengan metode freshcare ini:

a. Visual

Caranya ialah dengan membuat poster yang berisikan program pembinaan komunitas pemuda hijrah dengan gaya bahasa ring III dan ring IV. Contohnya dalam kajian keislaman; judul kajiannya itu Ngejapri Allah. Bahasa ngejapri itu biasa digunakan oleh anak-anak muda sekarang yang arinya ialah mengirim pesan kepada teman atau sahabanya. Namun, dalam kajian ini maksudnya ialah meminta sesuatu kepada Allah dengan cara berdoa. Makna japri ini sama dengan berdoa.

b. Audio Visual 
Caranya ialah dengan membuat video pendek berdurasi satu menit dengan materi yang telah dikemas dengan bahasa yang ringan. Contohnya dalam video di youtube atau instagram ketika ustadz Hanan Attaki menyampaikan tentang keutamaan kita dalam membantu saudara kita yang sedang kesulitan.

Kedua cara ini biasanya digunakan oleh pemuda hijrah ketika kajian keIslaman. Bilamana ada pemuda yang tidak bisa hadir pada saat jadwal kajian, bisa live streaming atau nonton langsung di media sosial, seperti instagram atau youtube. Kalau masih ketinggalan, bisa kunjungi akun youtubenya pemuda hijrah, di sana ada video-video hasil kajian yang di sampaikan oleh pemateri atau para pembina.

Kekuatan media sosial ini memang harus dimanfaatkan dengan mendengarkan dan melihat hal-hal yang positif. Disinilah komunitas pemuda hijrah berinisiatif melakukan hal itu, supaya masyarakat luas mendapatkan ilmu yang bermanfaat.

b. Metode Obrolan Santai

Obrolan Santai merupakan metode baru yang dipakai oleh komunitas pemuda hijrah, yaitu menyampaikan suatu materi agama Islam dengan jalan penuturan secara ngobrol antara pembina dan peserta, peserta dan peserta, sehingga mereka bisa sharing keilmuan tentang materi agama Islam sesuai dengan tema yang telah ditentukan. Di sini bebas berpendapat dan mempertanyakan banyak hal tentang Hukum atau Fiqh Islam, sejarah para sahabat, dan perjuangan Rasulullah SAW dalam menyebarkan ajaran agama Islam pada zamannya.

Ciri metode ini yang sangat menonjol adalah peran pembina yang bisa mengarahkan para peserta yang datang agar tidak terjadi debat kusir, sehingga mereka bebas berargumen namun memunculkan suatu ilmu yang baru bagi mereka dan semakin faham tentang materi yang disampaikan.

Biasanya metode obrolan santai ini digunakan ketika ada kegiatan Shift Ulin dan Giving Every Day. Dimana mereka saling bersatu, bersilaturahmi, sesuai dengan hobby dan kesukaannya, ngobrol dengan ekspresi serius dan becanda, sehingga mewarnai kehidupan mereka ketika berkumpul itu seperti saudara sendiri.

Selain itu para peserta binaan pemuda hijrah ini diberikan kesempatan untuk sharing permasalahan yang muncul di kehidupannya. Baik itu permasalahan pribadi, kelompok, sampai keluarga dan mencari solusi yang terbaik sesuai dengan aturan agama agar peserta binaan ini tenang dalam menjalani kehidupan yang akan dijalaninya ke depan.

Hikmah dari metode obrolan santai ini ialah mereka menjadi akrab satu sama lain, menambah keluarga dan teman sehingga dalam keadaan apapun mereka seperti keluarga, saling tolong menolong ketika kesulitan dan memberikan motivasi yang lebih, bahwa perjuangan hijrah dari yang dulunya 
aktif di dunia yang tidak disukai oleh Allah SWT kepada dunia yang disukai oleh Allah SWT itu banyak godaannya. Maka dari itu, dengan kita akrab dengan teman yang sama-sama mencari ilmu agama, proses hijrah pun akan mudah dan tentunya ada yang selalu mengingatkan jika kita lupa.

c. Metode Tikrar

Metode tikrar ialah salah satu upaya dari komunitas pemuda hijrah untuk memudahkan para peserta binaannya dalam menghafal Alquran. Metode ini digunakan ketika kegiatan tahsin dan tahfidz berlangsung. Dengan suasana yang berbeda, para peserta membaca dan menghafalnya di ruang terbuka, tepat di serambi masjid Al-Lathif setiap hari Senin, Selasa, dan Rabu pukul 10.00selesai.

Cara mudah menghafal Alquran dengan merode tikrar ialah membaca satu ayatnya itu sampai 40 kali bacaan hingga hafal. Untuk lebih memudahkan para peserta pembinaan ini, tersedianya mushaf tikrar yang dikeluarkan oleh syamil Quran, di dalamnya tersedia kolom untuk kita tandai berapa kali balikan satu ayat yang telah dibaca.

Dikolom inilah metode tikrar dimulai. Ada berapa tahapan yang mesti diperhatikan:

a. Baca ayat 13-14 sebanyak 40 kali, isi pada kolom 13-14. Agar tidak mengganggu, mengisi kolom bisa dilakukan per lima kali membaca atau per 10 kali membaca.

b. Baca ayat 15-16 sebanyak 40 kali, isi pada kolom 15-16.

c. Baca ayat 13-16 sebanyak 40 kali, isi pada kolom selanjutnya.

Ketiga tahapan membaca dengan metode tikrar ini, para peserta sudah mampu menghafal ayat Alquran sebanyak 4 ayat. Dari ayat 13-16 dalam surat Al-Baqoroh. Dengan metode seperti ini, para peserta akan lebih mudah dalam menghafal ayat-ayat yang ada di dalam Alquran.

Pada prakteknya, menghafal dengan mengajak teman dan saling bertukar hafalan akan lebih memudahkan kembali, karena akan saling memotivasi dalam menghafal Alquran.

Pada prinsipnya, ketiga metode pembinaan agama Islam yang dilakukan oleh pemuda hijrah ini ialah sebagai bentuk ikhtiar untuk mengajak ring III dan ring IV mengkaji tentang ilmu agama Islam agar mereka selamat dari kesesatan dan menyeru pada kebaikan.

\section{Penutup}

Berdasarkan rumusan masalah dan hasil penelitian dari beberapa permasalahan yang terungkap selama penelitian dilakukan, penulis dapat menarik kesimpulan sebagai berikut:

Bentuk kegiatan pembinaan komunitas pemuda hijrah, meliputi: Kajian keIslaman ialah mengkaji ilmu tentang ajaran agama Islam; Shift ulin ialah belajar agama Islam dengan cara bermain; Giving every day ialah kegiatan dengan mengajak bersedekah 
setiap hari sesuai dengan potensi mereka yang dimiliki; Qiyamul lail ialah ajakan solat tahajud dengan berjamaah; Tahsin dan tahfidz ialah pengajaran tentang Studi Alquran agar mereka mampu membaca dan menghafal sesuai makhroj dan tajwidnya; Pemuda Hijrah Peduli ialah gerakan sosial kemasyarakatan bilamana ada saudara atau tetangga yang terkena musibah, kita bantu sesuai dengan kemampuan; Ladies day ialah salah satu pengkhususan majlis taklim untuk para perempuan yang isinya membahas tentang kewajiban, larangan, dan batasan mereka dalam menjalani kehidupan.

Materi pembinaan agama Islam pemuda hijrah ini ada 3 materi pokok yang lebih ditekankan, diantaranya: Aqidah (Tauhid), Akhlak dan Studi Alquran yang pada akhirnya para peserta didik binaan pemuda hijrah ini rajin melaksanakan ibadah dan lebih dekat kepada Allah SWT serta menjalankan setiap perintah-Nya.

Metode pembinaan agama Islam yang digunakan oleh komunitas pemuda hijrah ini ada 3 metode, yaitu: Metode freshcare, Metode obrolan santai, dan Metode tikrar. Ketiga metode ini sangat efektif guna membantu keberhasilan pendidikan Islam di lingkup komunitas yang ada di dalam masyarakat.

\section{Bibliografi}

Barnawi, Bakir Yusuf (1993), Pembinaan Kehidupan Beragama Islam Pada Anak, Semarang: Dina Utama.

Bambang, Q.-A., \& Hambali, A. (2008). Pendidikan Karakter Berbasis Al Quran. Bandung: Simbiosa Rekatama Media.

Famularsih, S., \& Billah, A. (2014). Pola Pembinaan Keagamaan Anak Jalanan dalam Membentuk Kepribadian. MUDARRISA: Jurnal Kajian Pendidikan Islam, 6(1), 88-113.

Muhaimin. (2001). Rekonstruksi Pendidikan Islam: Dari Paradigma Pengembangan, Manajemen Kelembagaan, Kurikulum hingga Strategi Pembelajaran.

Thoha, dkk, Chabib (1999), Metodologi Pengajaran Agama. Yogyakarta: Pustaka Pelajar. 